\title{
Mechanism of Anti-Invasive Action of Docosahexaenoic Acid in SW480 Human Colon Cancer Cell
}

Soyeon Shin ${ }^{1,3^{\dagger}}$, Yong-Jo Kim ${ }^{1+}$, Kyoung-Sub Song ${ }^{1,3^{\dagger}}$, Kaipeng Jing ${ }^{1,3}$, Nayeong Kim ${ }^{1,3}$, Soyeon Jeong',3, Ji-Hoon Park', Kang-Sik Seo', Jun-Young Heo', Hyun-Joo Kwon', Jong-ll Park', Seung-kiel Park', Gi-Ryang Kweon', Wan-Hee Yoon ${ }^{1}$, Byung-Doo Hwang ${ }^{1}$ and Kyu Lim ${ }^{1,2,3}$ *

${ }^{1}$ Department of Biochemisty, ${ }^{2}$ Cancer Research Institute and ${ }^{3}$ Infection Signaling Network Research Center, School of Medicine, Chungnam National University, Daejeon, Korea

Received January 25, 2010 / Accepted February 20, 2010

\begin{abstract}
Colon cancer is one of the most common malignancies in the western world and the second leading cause of cancer death in Korea. Epidemiology studies have shown a reduced incidence of colon cancer among populations consuming a large quantity of $\omega 3$-polyunsaturated fatty acids ( $\omega 3$-PUFA) of marine origin. Recently, it has been found that 13 -PUFA has an antineoplastic effect in several cancers. This study was designed to investigate the mechanism of the anti-invasive effect of $\omega 3$-PUFA in colon cancer. $\omega 3$-PUFA, docosahexaenoic acids (DHA) and eicosapentaenoic acid (EPA) treatment resulted in a dose-dependent inhibition of cell growth in SW480 human colon cancer cells. In contrast, arachidonic acid (AA), a $\omega 6$-PUFA, exhibited no significant effect. This action likely involves apoptosis, given that DHA treatment increased apoptotic cells in TUNEL assay. Moreover, invasiveness of SW480 cells was inhibited following treatment of DHA in a dose-dependent manner; in contrast, AA had no effect. The levels of MMP-9 and MMP-2 mRNA decreased after DHA pretreatment. MMP-9 and MMP-2 promoter activities were also inhibited by DHA treatment. The levels of NF-kB and p-IkB protein were down-regulated by DHA pretreatment in a dose dependent manner. In addition, DHA inhibited NF-kB promoter reporter activities. These findings suggest that $\omega 3$-PUFA may inhibit cancer cell invasion by inhibition of MMPs via reduction of NF-kB in colon cancer. In conclusion, $\omega 3-P U F A$ could be used for chemoprevention and treatment of human colon cancer.
\end{abstract}

Key words : SW480, DHA, MMP-2, MMP-9, NF-kB

\section{서 론}

암은 산업이 발달되는 개발 도상국들에서 가장 높은 사망율 을 나타내는 질환[43]으로 전세계적으로 2020년에는 환자가 $50 \%$ 이상 증가되리라 예상되고 있다[74]. 이중 대장암은 가장 흔한 악성종양의 하나로 최근 점차 발생빈도가 증가하여 국내 외에서 악성종양 중 제 2 위의 발생빈도를 보이는 흔한 질환으 로 $[8,35,48]$ 근래에 진단방법과 외과적 기술의 발전 등으로 근 치적 절제율이 약 $80 \%$ 에 달하고 있음에도 불구하고 일반적 고형종양과 마찬가지로 5년 생존율은 약 $50 \%$ 정도로, 과반수 에 이르는 환자들이 암의 침윤에 의한 국소재발 또는 원격전 이에 의해 사망함으로 이들 암환자의 예후는 전적으로 진단시 의 전이성 병소의 존재 유무에 달려있다. 또한 원발종양 부위 를 외과적 적출 등의 근치적 처치방법으로 치료하더라도[9,45] 많은 경우에서 처음부터 미세 전이병소가 이미 존재하고 서서

\footnotetext{
${ }^{\dagger}$ These authors contributed equally to this work

*Corresponding author

Tel: $+82-42-580-8223$ (K.L.) and +82-42-580-8222 (B.-D.H.)

Fax : +82-42-580-8121

E-mail : kyulim@cnu.ac.kr (K.L.) and bdhwang@cnu.ac.kr (B.-D.H.)
}

히 성장해, 후에 전이병소로 뒤늦게 발견되어 치료가 불가능 해지기 때문에 암전이의 예방과 전이병소의 효과적인 치료는 종양관련 임상 및 많은 연구자들의 궁극적 목표가 되고 있다.

대장암의 발생빈도 및 사망률은 지역마다 차이가 나는 바 [27] 이에 대한 많은 역학조사가 시행되어 왔는데 알라스카 원주민에 대한 역학조사에서 이들은 폐암, 후두암, 방광암, 전 립선암, 유방암, 대장암등의 발생 빈도가 감소되어 있으며 이 는 많은 양의 $\omega 3$-polyunsaturated fatty acids ( $\omega 3$-PUFA)와 관 련되어 있음을 감안하여 지질을 포함한 식이인자가 암의 원인 및 진행에 중요하다[42]고 한다. PUFA는 막 인지질의 구성 물질뿐만 아니라 prostaglandin을 포함한 eicosanoids합성의 전단계 물질로써 중요하다[13,29]. $\omega 6$-PUFA인 arachidonic acid (AA) 및 $\omega 3$-PUFA인 eicosapentaenoic acid (EPA)로부터 합성된 eicosanoid들은 그 생리적인 기능이 다른 바 $\mathrm{AA}$ 로부 터 얻은 $\mathrm{PGE}_{2}$ 등은 암의 형성, 성장, 전이 등을 증가시키는 반 면에 $\mathrm{EPA}$ 로부터 얻은 $\mathrm{PGE}_{3}$ 는 이들 효과를 억제한다고 $[2,10,50,63,64]$ 한다. 그러나 생명체가 정상적인 성장 및 발달 을 위해서는 $\omega 6$-및 $\omega 3$-PUFA의 절대량 보다 $\omega 6 / \omega 3$-PUFA의 비율이 중요하며 이들 비율의 감소가 암을 포함한 질환의 예 방뿐만 아니라 치료에 중요하다고 $[3,26,39,49,70,71,84]$ 한다. 
일본인들도 대장암에 대한 발생빈도가 상대적으로 낮았으나 최근에는 서양식이를 함으로 그 발생빈도가 증가되었다고[52] 하여 대장암 발생과 육류섭취는 밀접한 상관관계가 있는 반면 에 생선의 섭취는 역상관 관계에 있다 $[58,67,83]$ 고 알려져 있 다. 오늘날 식이에는 $\omega 6$-PUFA 함량이 많아 $\omega 6 / \omega 3$-PUFA 비 율이 약 10 30:1로 매우 높아 $\omega 6$-PUFA를 많이 함유한 식이가 암의 발생 빈도를 높임으로[73], 따라서 생선에 다량 함유된 $\omega 3-P U F A$ 는 암 예방에 이롭고 육류에 다량 함유된 $\omega 6$-PUFA 는 암발생을 유도하리라 생각되고 있다. 또한 그린랜드 에스 키모인들은 서양인들에 비해 대장암 발생 빈도가 낮은데 $[11,41,61]$ 이는 이들의 식이의 $\omega 3-P U F A$ 함량이 서양식이 보 다 약 40 배가 높기 때문[65]이라고 한다.

화학적 발암물질에 의한 대장암 형성 모델에서 생선기름이 나 $\omega 3$-PUFA가 고농도로 포함된 식이를 섭취한 흰쥐들은 대장 암 발생이 감소하였으며 $[53,62,78,79]$, nude mice를 이용한 동물실험에서도 폐암을 포함한 많은 암의 종양 형성능이 $\omega$ 3-PUFA에 의해 감소됨으로 $[6,14,18,34,60] \omega 6-P U F A$ 는 암을 유도하나 $\omega 3$-PUFA는 암발생을 예방할 수 있다고 하였다.

$\omega 3$-PUFAs는 쉽게 세포막의 인지질에 전입되어[51] 막의 유 동성, 구조 및 기능을 바꾸거나 세포의 oxdative stress 및 PUFA의 대사물질 양의 변동을 초래하여 항암작용을 나타낸 다[17]고 한다. $\omega 3$-PUFA의 항암 기전에 대해서는 $\omega 3$-PUFA가 전사인자인 NF-kB [56,57,69], AP-1 [20,46] 등을 억제하여 이 들의 표적유전자의 전사가 억제됨으로 세포증식을 차단하거 나 또 Cox-2를 억제하여 PGE 2 합성의 감소를 유발한다[39,47]. 최근 $\mathrm{Lim}$ 등[44]은 Wnt/ß-catenin 신호전달 경로를 차단하여 간담도암 및 간암 세포의 apoptosis 유도한다고 하였다. Calviello 등[16]은 Cox-2가 발현되지 않은 대장암 세포에서도 $\omega 3$-PUFA가 $\beta$-catenin의 down-stream을 조절함으로 Cox-2 independent pathway에 의해 apoptosis도 유도된다고 하였 으며 Szymczak 등[77]은 human umbilical vein endothelial cell (HUVEC)에서 $\omega 3$-PUFA가 cyclooxygenase에 의해 혈관 신생을 조절할 수 있다고 하였다. 그러나 대장암의 침윤, 혈관 신생에 대한 $\omega 3-\mathrm{PUFA}$ 의 억제 기전에 대해서는 명확하게 밝혀 져 있지 않았다.

이에 본 연구에서는 먼저 대장암 세포주 SW480에서 docosahexaenoic acid (DHA) 등 $\omega 3$-PUFA에 의한 세포독성 기전 을 확인하고 이들에 의한 침윤능의 억제기전을 규명하여 약간 의 지견을 얻었기에 보고하는 바이다.

\section{재료 및 방법}

\section{실험재료}

Agarose, Dulbecco's Modified Eagle Medium (DMEM), fetal bovine serum등 세포배양에 필요한 시약들은 GIBCOBRL사(Gaithersburg, MD)에서, NF-kB의 p65 subunit, IkB, caspase-3, PARP, $\beta$-catenin, $\beta$-actin등의 항체는 Santa Crutz 사(California, DA), DHA, EPA, AA등은 Cayman Chemical 사(Ann Arbor, MI)에서, piperizine-N, N'-bis [2-ethanesulfonic acid] (PIPES), 3-[N-morpholino]propanesulfonic acid (MOPS), formaldehyde, formamide, ethidium bromide, phenol, sodium dodecyl sulfate (SDS) 등은 Sigma사(St. Louis, $\mathrm{MO}$ )에서, random prime DNA labeling kit, guanidine thiocyanate는 Boeringer Mannheim사(Mannheim, Germany)에 서 구입하였으며 그 외 다른 시약은 특급의 것을 사용하였다.

\section{대장암 세포주의 배양}

대장암 세포주 SW480의 배양은 10\% heat-inactivated fetal bovine serum (FBS), penicillin (100units/ml), streptomycin $(100 \mu \mathrm{g} / \mathrm{ml})$ 을 첨가한 $\mathrm{DMEM}$ 을 배양액으로 $5 \% \mathrm{CO}_{2}, 37^{\circ} \mathrm{C}$ 배양기에서 배양하고 세포의 밀도가 높아지면 수분간의 trypsin-EDTA (0.05\%trypsin, 0.02\% EDTA in Hank's balanced salt solution without calcium and magnesium)로 처리하고 실험 시 지수기에 있도록 계대배양 하였고, 모든 실험은 FBS가 포함되지 않은 배지로 교환한 다음 24 시간 후 사용하였다.

\section{세포 증식능 검색}

대장암 세포주의 증식능에 대한 DHA 등의 영향은 colorimetric MTT assay를 이용해 측정하였다. 즉 96 well microtiter tissue culture plate에 대장암 세포를 5-10×10 $0^{3}$ cells/well로 plating하고 하룻밤 배양 후 FBS가 포함되지 않은 배지로 교환 한 다음 24시간 배양하고 DHA 등을 농도별로 처리하였다. 24시간 배양한 다음 세포의 배양액을 제거하고 MTT (0.5 $\mathrm{mg} / \mathrm{ml}$ ) 용액으로 $37^{\circ} \mathrm{C}$ 에서 2 시간 반응시키고 상청액을 제거 한 후 $\mathrm{DMSO}$ 에 녹여 $570 \mathrm{~nm}$ 에서 automatic ELISA plate reader로 흡광도를 측정하였다.

\section{TUNEL assay}

SW480 세포를 $5 \times 10^{4}$ cells/well로 cover glass가 들어있는 24-well plate에 plating한 후 DHA 처리하여 24시간 동안 배양 하였다. 이들 세포를 PBS로 2회 washing한 다음 $4 \%$ paraformaldehyde로 $4^{\circ} \mathrm{C}$ 에서 20 분간 고정시킨 다음 $0.2 \%$ TritonX-100으로 처리한 후 DeadEND Fluorometric TUNEL System (Promega 사) kit를 사용하여 분해된 DNA에 anti-digoxigenin-phosphatase를 $37^{\circ} \mathrm{C}$ 에서 4 시간 동안 반응시켜 붙 였다. 이들 세포는 PBS로 3회 washing한 후 DAB를 이용하여 발색 시킨 후 DAPI로 핵을 염색한 것을 mounting medium을 넣고 coverslip으로 밀봉시켜 confocal microscopy (Olympus ${ }^{\mathrm{TM}}$ )로 검경, 촬영하였다.

Western blot

Western blot은 Kim 등의 방법[36]에 따라 시행하였다. 즉 
SDS-PAGE 후에 분리된 단백을 전기적 전사법으로 nitrocellulose membrane에 옮긴 후 전사된 nitrocellulose membrane을 5\% skim milk로 실온에서 1시간 blocking한 다음 동 일 용액으로 PARP, caspase- $3, \beta$-actin 등의 antibody $(1: 1,000)$ 로 $4^{\circ} \mathrm{C}$ 에서 하룻밤 반응시켰다. 이 후 TBS-T로 수회 세척하고 peroxidase conjugated secondary antibody를 5\% skim milk/TBS-T용액에 1:10,000으로 희석하여 1시간 반응 시키고 TBS-T로 수회 세척한 후 ECL Western blotting detection system을 이용하여 단백질 band를 확인하였다.

\section{Transfection and luciferase reporter 활성 측정}

SW480 세포를 6-well culture plate에 80\% confluent하게 plating한 후 $0.5 \mu \mathrm{g} /$ well로 TCF-LEF-Luc reporter plasmid 등을 lipofectamine을 이용하여 transfection 하였다. Transfection 된 세포에 DHA 등의 약물을 처리하여 일정시간 배양한 후 세포를 1X reporter lysis buffer로 lysis 하고 얻은 효소액을 luciferase assay system (Promega사, USA)을 이용하여 반응 시킨 후 Luminometer (Thermo사, USA )로 luciferase 활성을 측정하였다. Luciferase 활성의 측정은 효소액의 단백질 양을 측정한 후 동일한 단백질 양으로 조절한 다음 시행하였다.

\section{In vitro 침윤능 측정}

Transwell chamber를 통한 침윤능의 측정은 Yoon 등[85]의 방법에 따라 시행하였다. 즉, $6.5 \mathrm{~mm}$ 직경의 $8 \mu \mathrm{m}$ pores를 가진 polycarbonate filter를 내장한 transwell culture chamber (Costa, Cambridge, MA)를 이용하였다. 즉 침윤능 검색을 위하여 filter위에 $160 \mu \mathrm{g}$ 의 Matrigel을 도포시킨 후 $37^{\circ} \mathrm{C}$ 에서 2시간 배양하여 젤화되도록 한 다음 세포현탁액 $200 \mu \mathrm{l}\left(2 \times 10^{5}\right.$ cells)를 upper chamber에 넣고 lower chamber에는 DHA가 포함된 배양액을 넣은 후 일정시간 배양시켰다. 배양이 끝나 면 filter 윗면의 세포들을 면봉을 이용해 제거한 후 filter를 분리해 hematoxylin-eosin으로 염색한 다음 현미경을 이용해 filter 아랫면의 세포수를 검경 계수하여 판독하였다.

\section{Total RNA 조제}

Total RNA는 Ultraspec ㅍ Kit (Biotecx Lab. Inc, USA)을 이용하여 조제하였다. 즉, 각 약물을 처리한 SW480 세포를 일정 시간 배양한 후에 배지를 제거하고 PBS로 2회 씻은 다음 PBS $1 \mathrm{ml}$ 씩을 가해 세포를 수집하여 원심한 후 여기에 Ultraspec $\Pi$ 용액을 일정량 가하여 세포를 용해시켜 $4^{\circ} \mathrm{C}$ 에서 5 분간 방치한 후 0.1 배 용량의 chloroform용액을 가하고 진탕, 혼합하였다. 이를 다시 $4^{\circ} \mathrm{C}$ 에서 5 분간 방치하고, $4^{\circ} \mathrm{C}$ 에서 $12,000 \mathrm{rpm}$ 으로 15 분간 원심분리 하였다. 원심분리 후 상청액 을 취하고 이에 0.5 배 용량의 isopropyl alcohol을 가한 후 다시 Ultraspec $\Pi$ resin을 0.05배 용량을 가하여 진탕혼합하고 $12,000 \mathrm{rpm}$ 에서 1 분간원심분리 하였다. 이때 얻은 침전물을
$70 \%$ ethanol로 2회 씻고 침전물을 녹여 resin에 결합되어 있는 RNA를 용출시켰다. Total RNA는 사용할 때까지 $50 \%$ ethanol 용액에서 $-70^{\circ} \mathrm{C}$ 에 보관하였다.

\section{Reverse Transcriptase Polymerase Chain Reaction (RT-PCR) \\ $\mathrm{DHA}$ 가 처리된 세포와 대조군 세포로부터 각각 조제한 to-} tal RNA $1 \mu \mathrm{g}, 8 \mu \mathrm{l}$ 의 5× RT buffer (250 mM Tris- $\mathrm{HCl}, \mathrm{pH}$ 8.3, $250 \mathrm{mM} \mathrm{KCl}, 50 \mathrm{mM} \mathrm{MgCl} 2,2.5 \mathrm{mM}$ spermidine, $50 \mathrm{mM}$ DTT), $2.5 \mathrm{mM}$ dNTP $4 \mu \mathrm{l}$, oligo-dT (100 pmol/ $\mu \mathrm{l}) 1 \mu \mathrm{l}$, RNase inhibitor (4 unit/ $\mu \mathrm{l}) 2 \mu \mathrm{l}$, AMV reversetranscriptase (5 unit/ $\mu$ l) $2 \mu \mathrm{l}$ 를 $42^{\circ} \mathrm{C}$ 에서 1 시간 동안 반응하여 single-strand cDNA 를 합성하였다. 이를 MMP-9 및 MMP-2 유전자의 primer (MMP-2: Forward: 와 dNTP, Taq polymerase, Taq buffer등 과 섞어 $94^{\circ} \mathrm{C} 1$ 분, $65^{\circ} \mathrm{C} 1$ 분, $72^{\circ} \mathrm{C} 1$ 분씩 30 cycle을 반응시킨 후 $1.5 \%$ agarose gel에 전기영동하여 그 변동을 확인하였다. MMP-9 및 MMP-2의 primer 서열은 Table 1 과 같다.

\section{통계분석}

표시된 결과는 3번 이상의 독립적인 실험 결과이며, 실험 결과의 통계 처리는 student's t-test에 준하여 처리하였고, $P$-value가 최대치 $0.05(p<0.05)$ 이하인 경우를 유의한 것으로 판정하였다.

\section{결 과}

\section{인체 대장암세포 SW480의 증식에 미치는 $\omega 3-P U F A$ 의 영향}

$\omega 3$-PUFA는 $\omega 6-\mathrm{PUFA}$ 와는 달리 간담도암을 비롯한 수종의 암세포주에 대해 세포독성을 나타낸다[17,44]고 알려져 있다. 이에 먼저 인체 대장암 세포주 SW480에 대한 $\omega 3$-PUFA의 세 포 독성을 $\omega 6-\mathrm{PUFA}$ 와 비교, 확인하였다. 이때 $\omega 3$-PUFA로는 $\mathrm{DHA}, \mathrm{EPA}$ 를, $\omega 6-\mathrm{PUFA}$ 로는 AA를 사용하였다. 96 well tissue plate에 SW480 세포를 $0.5-1 \times 10^{4}$ cells/well로 배양한 다음 무혈청 배지로 24 시간 배양하고 $1-25 \mu \mathrm{M}$ 의 $\omega 3$-PUFA를 처리 하여 24시간 후 MTT로 세포 증식능을 검색하였다. DHA 및 $\mathrm{EPA}$ 는 SW480 세포의 증식을 농도의존적으로 억제하였으나 $\mathrm{AA}$ 는 거의 영향이 없었다(Fig. 1A). $\omega 3$-PUFA에 의해 억제된

Table 1. Primer sequences of MMP-2 and MMP-9 genes for RT-PCR

\begin{tabular}{lll}
\hline Primer & \multicolumn{2}{c}{ Primer sequences } \\
\hline \multirow{2}{*}{ MMP-2 } & $\begin{array}{l}\text { Forward } \\
\text { 5everse }\end{array}$ & 5'-GGCCCTGTCACTCCTGAGAT-3' $^{\prime}$-GGCCAGGTTATCGGGGA-3' \\
\hline \multirow{2}{*}{ MMP-9 } & $\begin{array}{l}\text { Forward } \\
\text { Reverse }\end{array}$ & 5'-TGGACGATGCCTGCAACGTG-3' $^{\prime}$-GTCGTGCGTGTCCAAAGGCA-3' \\
\hline
\end{tabular}


A

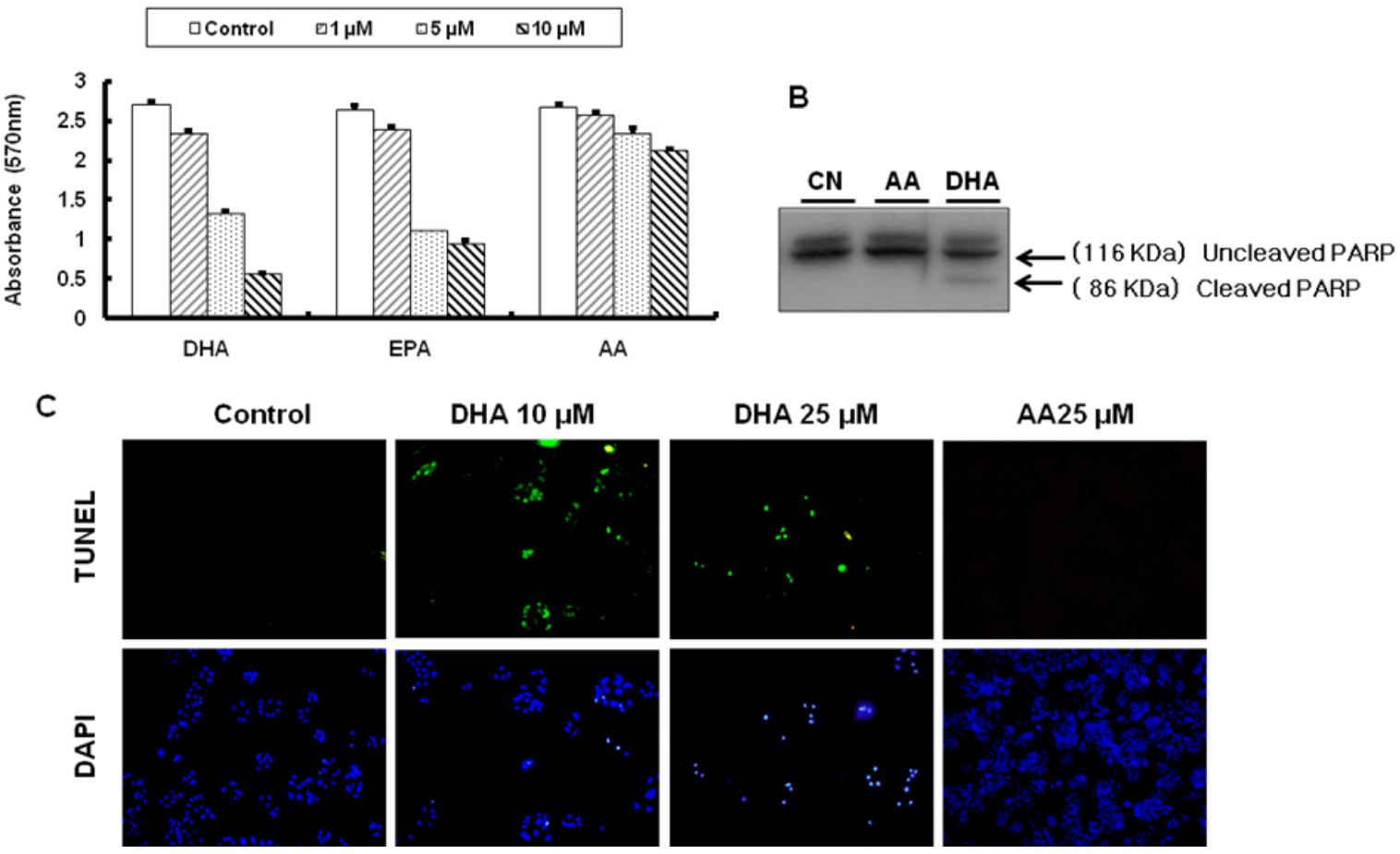

Fig. 1. Effects of DHA, EPA and AA on cell proliferation of SW480 human colon cancer cell. A, SW480 were incubated with different concentrations of DHA, EPA, and AA for $24 \mathrm{hr}$, and cell growth was determined using the MTT assay as described in Materials and Methods. B, DHA induced dose-dependent apoptosis. Cells were treated with various concentrations of DHA for 24 hour and the proportion of apoptotic cells was determined by TUNEL assay as described in Materials and Methods.

SW480세포의 증식에 apoptosis가 관련되어 있는지 확인하기 위해 apoptotic molecule의 하나인 PARP을 검색했을 때 DHA 의 처리 후에는 cleaved PARP이 증가하였으나 $\mathrm{AA}$ 에 의해서 는 전혀 영향이 없었다(Fig. 1B) 또한 DHA 처리 후 TUNEL assay를 시행하였을 때 DHA를 처리 후 SW480 세포는 DHA 의 농도에 의존적으로 apoptotic cello이 증가하였다. 한편 AA 처리 후에는 대조군에 비해 apoptotic cell의 변동이 관찰되지 않았다(Fig. 1C). 이는 DHA등 $\omega 3$-PUFA는 $\omega 6$-PUFA인 AA와 는 달리 대장암세포에 대해 세포 독성이 있으며 이에 apoptotic cell death가 관련되어 있음을 시사한다.

대장암 세포에서 $\beta$-catenin 발현 및 TCF/LEF reporter 활성에 대한 $\mathrm{DHA}$ 의 영향

많은 암의 생성에 Wnt signaling이 관련되어 있다 $[19,28,33,54]$ 고 알려져 있으며, 최근 $\operatorname{Lim}$ 등[44]은 간암 및 간 담도암에 대한 $\omega 3-P U F A$ 의 세포독성기전에 Wnt signaling에 관련된 $\beta$-catenin 분해가 중요하다고 하였다. 이에 먼저 대장 암 세포 SW480에 5-50 $\mu \mathrm{M}$ 의 DHA를 처리 후 $\beta$-catenin 단백 질 양을 Western blot으로 검색하였을 때 $\beta$-catenin 단백질 양 은 처리한 $\mathrm{DHA}$ 의 농도에 의존적으로 감소하였다(Fig. 2A). 이는 DHA에 의한 대장암 세포의 apoptosis 기전에 Wnt sig- nal pathway가 관련되어 있음을 시사한다.

$\beta$-catenin은 TCF/LEF 전사인자와 결합하고 이 복합체가 다 시 TCF/LEF response element와 결합한 후 그 표적유전자들 의 전사를 유도한다 $[1,12,66]$. 최근 $\omega 3$-PUFA가 수종의 암세포 에서 TCF/LEF의 reporter 활성을 억제한다고 보고[16]되어 있으며 $\operatorname{Lim}$ 등은 간암[44] 및 담도암에서 $\mathrm{DHA}$ 가 TCF/LEF reporter 활성을 억제한다고 하였다. 이에 대장암세포에서 $\mathrm{TCF} / \mathrm{LEF}$ reporter 활성에 대한 DHA의 영향을 밝히기 위해 6 well tissue plate에 대장암 세포 SW480을 배양하여 TCF/ LEF reporter vector를 transfection한 후 5-50 $\mu \mathrm{M}$ 의 DHA를 처리한 다음 24시간 후 luciferase activity를 측정하였다. SW480 세포에서 DHA 처리 후 TCF/LEF reporter의 luciferase 활성은 $\mathrm{DHA}$ 의 농도에 의존적으로 감소하였다(Fig. 2B). 이는 $\mathrm{DHA}$ 에 의해 $\beta$-catenin의 단백질 양이 감소하고 따라서 $\mathrm{TCF} / \mathrm{LEF}$ reporter활성이 감소되었음을 시사한다.

\section{대장암 세포의 침윤능에 미치는 $\mathrm{DHA}$ 의 영향}

Szymczak 등[77]은 $\omega 3$-PUFA가 인체 탯줄에서 유래된 혈관 내피세포 (HUVEC)의 침윤을 억제한다고 하였고, Yun 등[86] 은 유방암세포에서 $\omega 3$-PUFAs가 세포의 운동능 및 침윤능을 억제한다고 하였다. 이에 DHA의 대장암세포에 미치는 영향 
A

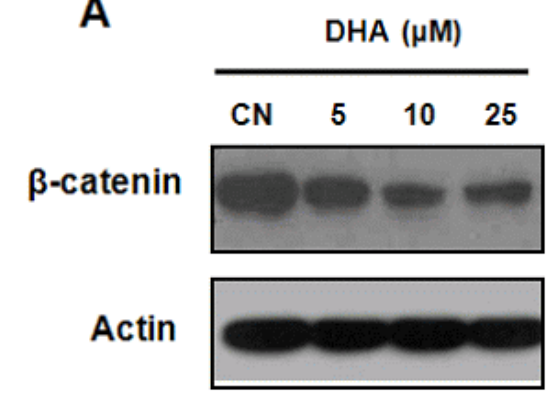

B

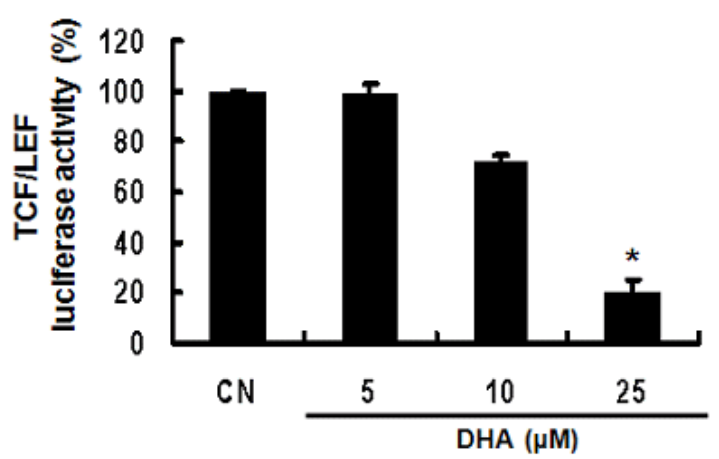

Fig. 2. Effect of DHA on the level of TCF/LEF reporter activity and $\beta$-catenin protein in SW480 cells. A, Cells were treated with various concentration of DHA for $24 \mathrm{hr}$ and harvested. The levels of $\beta$-catenin was analysed by Western blot analysis as described in Meterials and Methods. B, SW480 cells were plated and TCF/LEF luciferase reporter gene was transfected using lipofectam in reagent as described in Materials and Methods. After the transfection performed, the cells were treated with DHA for $24 \mathrm{hr}$, and then the luciferase activity was measured using the dual luciferase assay system (Promega). CN, control; Columns, mean of four independent experiments; bars, SD; *, $p<0.05$ compared with control; **, $p<0.01$ compared with control.

이 세포독성 외에도 세포의 침윤능을 억제할 수 있는가를 밝히 기 위해 대장암세포의 침윤능을 검색하였다. 대장암세포 SW480 을 transwell chamber에 $5 \times 10^{5}$ cells/well로 조절하고 $5,10 \mu \mathrm{M}$ 의 DHA로 처리한 다음 48시간 후에 filter를 통해 이동한 세포 를 측정하여 침윤능을 검색하였을 때 $\mathrm{DHA}$ 에 의한 SW480 세 포의 침윤능은 농도 의존적으로 억제되었으나 $\mathrm{AA}$ 는 전혀 영 향이 없었다(Fig. $3 \mathrm{~A}, 3 \mathrm{~B})$. 이는 $\mathrm{DHA}$ 에 의한 대장암세포의 침 윤 억제는 $\omega 3-P U F A s$ 에 선택적인 작용임을 시사한다.

대장암 세포에서 MMP-9 및 MMP-2 유전자 발현에 대한 $\mathrm{DHA}$ 의 영향

암세포의 침윤에는 MMP-9 등 matrix metalloproteinases (MMPs)들의 활성이 중요하며[25,55,59,76] 최근 Yun 등[86]은 유방암세포에서 DHA에 의해 MMP-9 및 MMP-2 유전자 발현
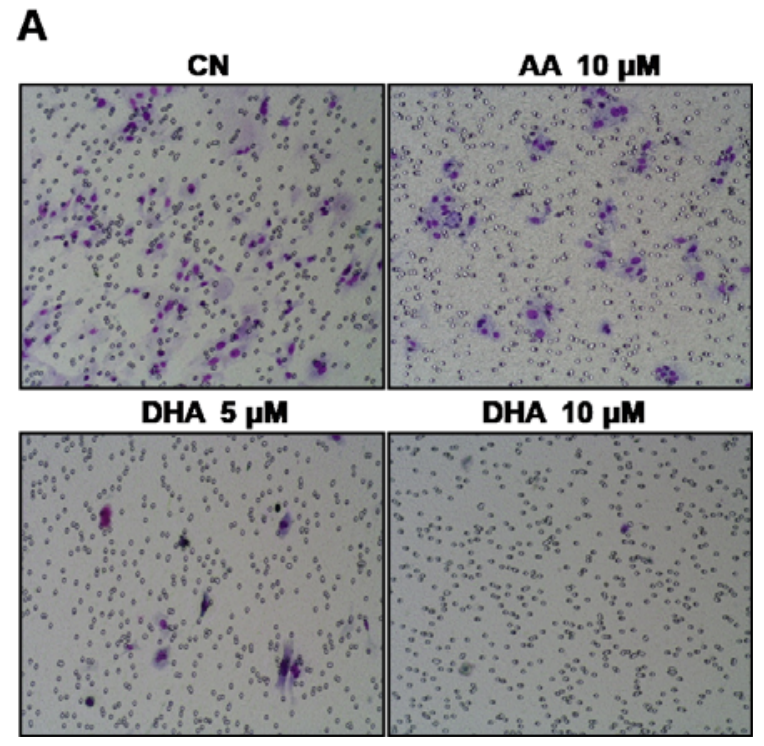

B

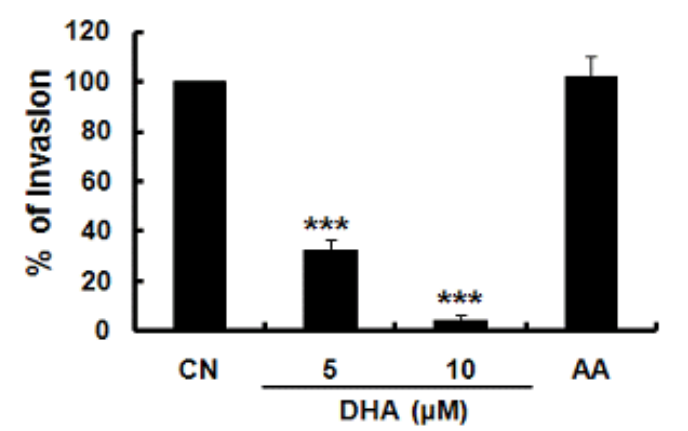

Fig. 3. Effect of DHA on invasion of SW480 cells. The cells were loaded onto matrigel-coated upper chamber transwell as described in Materials and Methods. The cells were treated with DHA and AA. After $48 \mathrm{hr}$, the filtrated cells were stained. A, Microphotographs of filters and quantitative analysis of matrigel chamber invasion assay are shown. $\mathrm{B}$, Numbers of invasive cells (mean $\pm \mathrm{SD}$ ) counted in 10 random fields. $\mathrm{CN}$, control; $\mathrm{AA}$, arachidonic acid; bars, $\mathrm{SD} ;{ }^{* * *}, p<0.001$ compared with control.

이 억제된다고 하였다. 이에 대장암 SW480 세포에서 DHA에 의한 MMP-9 및 MMP-2 발현의 변동을 검색하기 위하여 $\mathrm{DHA}$ 처리 후 total RNA를 조제하여 RT-PCR을 시행한 바 농도의존적으로 MMP-9 및 MMP-2 mRNA양이 감소하였으 나(Fig. 4A) AA에 의해서는 영향이 없었다. 이는 SW480 세포 에서 DHA에 의한 MMP-9 및 MMP-2 유전자 발현의 억제가 $\omega 3$-PUFA의 특이 작용임을 시사하는 것이다.

대장암세포에서 MMP-2및 MMP-9 promoter 활성에 대 한 $\mathrm{DHA}$ 의 영향

상기 실험에서 DHA에 의해 MMP-2 및 MMP-9 mRNA양 
A

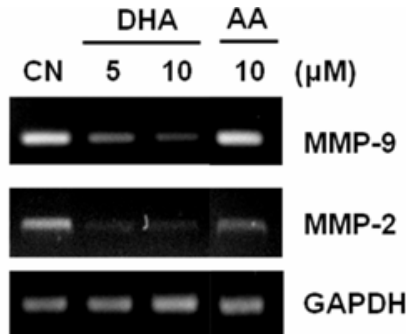

B

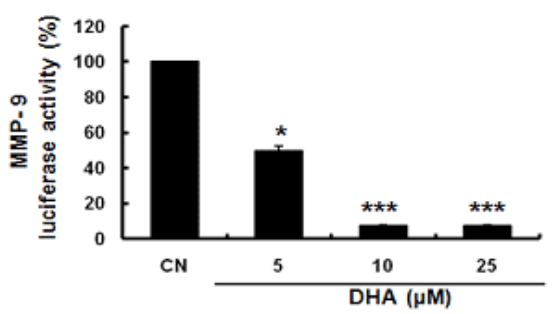

C

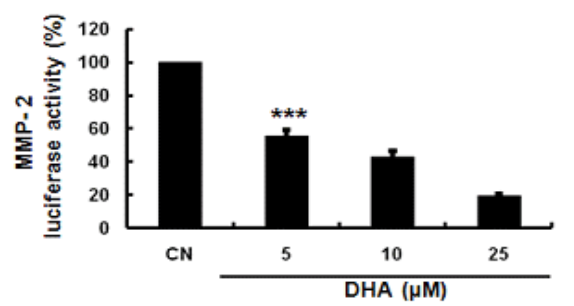

Fig. 4. Effect of DHA on MMP-2 and MMP-9 expression in SW480 cells. A, The cells were treated with various concentration of DHA for $24 \mathrm{hr}$ and were harvested. The levels of MMP-2 and MMP-9 mRNA were analysed by RT-PCR as described in Materials and Methods. B and C, SW480 cells were plated and MMP-9 and MMP2 luciferase reporter genes were transfected by using lipofectamin reagent as described in Materials and Methods. After the transfection was performed, the cells were treated with DHA for $24 \mathrm{hr}$. The luciferase activity was measured using the dual luciferase assay system (Promega) luminometer (Thermo). CN, control; columns, mean of four independent experiments; bars, SD; *, $p<0.05$ compared with control; $* * *, p<0.001$ compared with control.

이 각각 감소하였는데 이들의 억제가 전사 단계에서 조절되는 지 확인하기 위해 DHA 처리 후 의해 MMP-2 및 MMP-9의 promoter 활성을 측정하였다. 대장암세포 SW480을 배양하여 MMP-2 및 MMP-9 promoter 유전자가 포함된 reporter plasmid를 transient transfection 후 그 활성에 대한 DHA의 영향을 lucifersae 활성을 측정함으로 검색하였다. MMP-2 및 MMP-9 promoter의 luciferase 활성은 SW480 세포에서 DHA 처리 후 억제되었으며 이는 농도의존적으로 나타났다(Fig. 4B, 4C).

\section{대장암 세포에서 NF-kB 활성에 대한 DHA의 영향}

NF-kB는 전사인자로써 염증반응에 관련되어 있는 IL-1 $\beta$, TNF- $a$ 등 염증분자들의 조절에 관련되어 있을 뿐만 아니라 $[4,82,87]$ 과발현시 암세포의 apoptosis를 억제하여 암세포의 증식을 유도하나[7] $\omega 3$-PUFA는 NF-kB의 활성을 감소시킨다 $[56,57]$ 고 알려져 있다. 또한 MMP-9 [5,24] 유전자등의 promoter에는 공통적으로 NF-kB가 결합할 수 있는 cis element가 존재한다고 한다. 이에 DHA에 의한 NF-kB 활성변동을 검색 하기 위해 먼저 NF-kB subunit 중 하나인 p65 와 p-lkB 단백질 양의 변동을 검색하였다. SW480 세포에 DHA를 5-25 $\mathrm{MM}$ 농도 로 처리하였을 때 $\mathrm{p} 65$ 및 $\mathrm{p}-\mathrm{IkB}$ 의 단백질 양이 농도의존적으 로 감소하였다(Fig. 5A). 또한 대장암 세포 SW480 세포에서 NF-kB binding element를 가진 reporter plasmid를 transient transfection 후 DHA의 영향을 검색한 바 DHA 처리 후 NF-kB reporter 활성은 감소하였으며 이는 농도의존적으로 나타났다(Fig. 5B). 이는 대장암 세포에서 DHA가 NF-kB 단백 의 분해를 증가시켜 MMP-9등의 발현을 억제하여 침윤을 억 제할 수 있음을 시사한다.

\section{고 찰}

$\omega 3$-PUFA는 암 발생을 억제하는데 비해 $\omega 6-P U F A$ 는 암 발

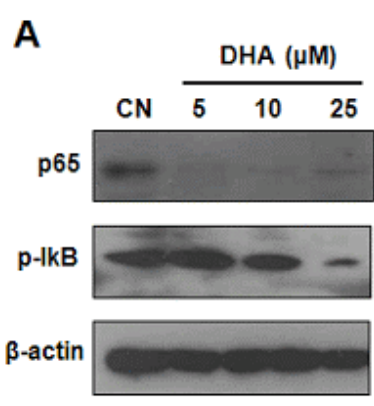

B

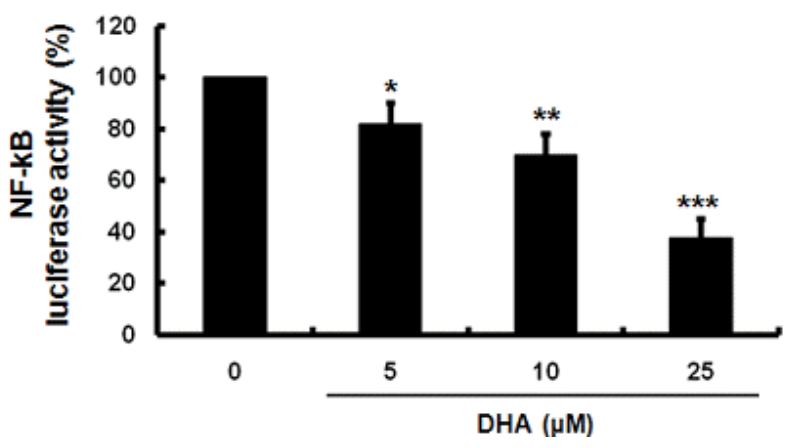

Fig. 5. Effect of DHA on the level of NF-kB protein and promoter activity in SW480 cells. A, The cells were treated with various concentration of DHA for $24 \mathrm{hr}$. p65 and phospho-IkB protein level were analysed by Western blot analysis as described in Materials and Methods. B, SW480 cells were plated and NF- $\mathrm{kB}$ promoter luciferase reporter plasmid were transfected. After cells were treated with DHA for $24 \mathrm{hr}$, the luciferase activity was measured as described in Materials and Methods. CN, control; columns, mean of four independent experiments; bars, SD; *, $p<0.05$ compared with control; ${ }^{* *}, p<0.01$ compared with control; ${ }^{* * *}, p<0.001$ compared with control. 
생을 촉진시킨다 $[3,26,39,49,70,71,84]$ 고 한다. 특히 동물실험에 서 $\mathrm{EPA}$ 및 $\mathrm{DHA}$ 를 먹인 생쥐에서 폐[32,37], 대장[6,14, $18,34,60]$ 유방[22,30,31], 전립선[21], 암 등에 대한 종양 형성능 이 억제된다고 알려져 있다. 또한 대장암 세포에서 $\omega 3$-PUFA 는 apoptosis 통해 세포 독성을 나타내며 cell cycle을 정지한다 $[15,23,36,68]$ 고 한다. 이에 본 연구에서도 먼저 대장암 세포주 SW480에서 DHA 및 EPA처리 한 후 세포성장이 억제 되었으 며 TUNEL assay에서 DHA에 의해 농도 의존적으로 apoptotic cell이 증가하였으나 w6-PUFA인 AA에 의해서는 전혀 영향이 없었는데 이는 대장암세포인 SW480에서 DHA등 $\omega$ 3-PUFA가 apoptosis를 유도하여 세포독성을 나타남을 시사 하는 것이다.

많은 대장암 세포주에서 $\beta$-catenin이 과발현되어 있으며 [75], 이들 세포들이 EPA 및 DHA에 의해 억제 된다[38,81]고 한다. Lim 등[44]도 $\omega 3$-PUFA가 AA와는 달리 $\beta$-catenin/ GSK3 $\beta$ 를 통하여 분해함으로 간담도암 및 간암세포를 apoptosis 시킨다고 하였다. 이에 본 연구에서도 SW480 세포에서 $\mathrm{DHA}$ 에 의한 $\beta$-catenin의 발현을 검색했을 때 농도 의존적으 로 감소하였고 $\beta$-catenin에 의해 조절 받는 TCF/LEF luciferase 활성도 억제되었는데, 이는 DHA에 의한 대장암 세포의 증식 억제능이 $\beta$-catenin을 통한 downstream 유전자 조절에 의해 일어날 수 있음을 시사하는 것이다.

암세포의 침윤에는 MMP-2 및 MMP-9등 MMPs가 중요하 다[25,55,59,76]고 한다. 최근 $\omega 3$-PUFA의 신생 혈관 신생 및 침윤의 억제작용이 있다고 보고[72,86] 되어 왔다. 이에 본 연 구에서 먼저 대장암 세포인 SW480의 침윤능에 대해 검색한 바 DHA에 의해서는 농도 의존적으로 침윤능이 억제되었으나 $\omega 6$-PUFA인 AA에 의해서는 거의 영향이 없었으므로 DHA에 의한 대장암세포의 침윤능의 억제 작용도 $\omega 3-\mathrm{PUFA}$ 의 특이 작용이라 생각된다. 또한 암세포의 침윤에 중요한 MMP-2 및 MMP-9의 mRNA 뿐만 아니라, 그들 promoter 활성도 DHA 처리 후 감소하여 대장암 세포의 DHA에 의한 침윤 억제에 MMP-2 및 MMP-9 활성 억제가 밀접히 관련되어 있음을 시사 한다.

$\mathrm{NF}-\mathrm{kB}$ 는 전사인자의 일종으로 과발현 시켰을 때 암세포의 apoptosis가 억제되어 암세포의 성장을 촉진한다[7]고 하며 또 한 $\omega 3$-PUFA가 NF-kB를 억제하여 암세포의 apoptosis가 유도 한다[11,56,57]고 한다. MMP-9 $[5,24]$ 및 VEGF $[40,80,86]$ 등 암세포의 침윤 및 혈관신생에 중요한 단백질들의 유전자 promoter 에는 NF-kB가 결합하는 cis element를 공통적으로 가지 고 있다. 최근 Yun 등[86]은 유방암 세포에서 경향과 일치하였 으며 DHA에 의한 NF-kB 단백의 감소에는 IKK 억제에 따른 $\mathrm{IkB}$ 의 인산화가 감소됨으로 일어난다고 하였다. 본 실험에서 SW480 세포에 DHA를 처리했을 때 NF-kB의 p65 subunit 및 $\mathrm{p}-\mathrm{IkB}$ 의 단백질 양이 DHA의 농도에 의존적으로 감소하였을 뿐만 아니라 NF-kB reporter 활성도 감소하였는데, 이는 Yun
등[86]의 유방암 세포에서의 일치하였으며, DHA에 의해 NF-kB 단백이 파괴됨으로 핵으로의 이동이 되지 않아 MMP-9 등의 생성이 감소될 수 있음을 시사한다.

이상의 결과로 $\omega 3$-PUFA는 첫째, $\beta$-catenin의 감소에 따른 Wnt signal을 억제하며 둘째, MMP-2 및 MMP-9 등matrix matalloproteinase의 억제를 통한 대장암 세포의 침윤능 억제 셋째, NF-kB 억제에 따른 표적 분자 발현 억제 등 복합적 기전 에 의해 항암작용을 나타내리라 생각되며 따라서 대장암의 치료 및 예방 목적으로 유용하게 사용할 수 있으리라 시사된다.

\section{감사의 글}

본 연구는 2007년도 충남대학교 학술연구비에 의해 지원되 었음.

\section{References}

1. Aberle, H., A. Bauer, J. Stappert, A. Kispert, and R. Kemler. 1997. beta-catenin is a target for the ubiquitin-proteasome pathway. ЕMBO. J. 16, 3797-3804.

2. Abou-el-Ela, S. H., K. W. Prasse, R. L. Farrell, R. W. Carroll, A. E. Wade, and O. R. Bunce. 1989. Effects of D,L-2-difluoromethylornithine and indomethacin on mammary tumor promotion in rats fed high n-3 and/or n-6 fat diets. Cancer Res. 49, 1434-1440.

3. Berquin, I. M., Y. Min, R. Wu, J. Wu, D. Perry, J. M. Cline, M. J. Thomas, T. Thornburg, G. Kulik, A. Smith, I. J. Edwards, R. D'Agostino, H. Zhang, H. Wu, J. X. Kang, and Y. Q. Chen. 2007. Modulation of prostate cancer genetic risk by omega-3 and omega- 6 fatty acids. J. Clin. Invest. 117, 1866-1875.

4. Bhattacharya, A., D. Sun, M. Rahman, and G. Fernandes. 2007. Different ratios of eicosapentaenoic and docosahexaenoic omega-3 fatty acids in commercial fish oils differentially alter pro-inflammatory cytokines in peritoneal macrophages from C57BL/6 female mice. J. Nutr. Biochem. 18, 23-30.

5. Bond, M., A. J. Chase, A. H. Baker, and A. C. Newby. 2001. Inhibition of transcription factor NF-kappaB reduces matrix metalloproteinase-1, -3 and -9 production by vascular smooth muscle cells. Cardiovasc Res. 50, 556-565.

6. Boudreau, M. D., K. H. Sohn, S. H. Rhee, S. W. Lee, J. D. Hunt, and D. H. Hwang. 2001. Suppression of tumor cell growth both in nude mice and in culture by $n-3$ polyunsaturated fatty acids: mediation through cyclooxygenase-independent pathways. Cancer Res. 61, 13861391.

7. Bours, V., M. Bentires-Alj, A. C. Hellin, P. Viatour, P. Robe, S. Delhalle, V. Benoit, and M. P. Merville. 2000. Nuclear factor-kappa B, cancer, and apoptosis. Biochem. Pharmacol. 60, 1085-1089.

8. Boyle, P. and J. Ferlay. 2005. Cancer incidence and mortality 
in Europe, 2004. Ann. Oncol. 16, 481-488.

9. Bresalier, R. S., C. R. Bol, and, and Y. S. Kim. 1984. Characteristics of colorectal carcinoma cells with high metastatic potential. Gastroenterology 87, 115-122.

10. Brown, M. D., C. A. Hart, E. Gazi, S. Bagley, and N. W. Clarke. 2006. Promotion of prostatic metastatic migration towards human bone marrow stoma by Omega 6 and its inhibition by Omega 3 PUFAs. Br. J. Cancer 94, 842-853.

11. Byers, T. 1996. Nutrition and cancer among American Indians and Alaska Natives. Cancer 78, 1612-1616.

12. Cadigan, K. M. and R. Nusse. 1997. Wnt signaling: a common theme in animal development. Genes Dev. 11, 3286-3305.

13. Calder, P. C., P. Yaqoob, F. Thies, F. A. Wallace, and E. A. Miles. 2002. Fatty acids and lymphocyte functions. $\mathrm{Br}$ J Nutr. 87 Suppl 1, S31-S48.

14. Calviello, G., F. Di Nicuolo, S. Gragnoli, E. Piccioni, S. Serini, N. Maggiano, G. Tringali, P. Navarra, F. O. Ranelletti, and P. Palozza. 2004. n-3 PUFAs reduce VEGF expression in human colon cancer cells modulating the COX-2/PGE2 induced ERK-1 and -2 and HIF-1alpha induction pathway. Carcinogenesis 25, 2303-2310.

15. Calviello, G., F. Di Nicuolo, S. Serini, E. Piccioni, A. Boninsegna, N. Maggiano, F. O. Ranelletti, and P. Palozza. 2005. Docosahexaenoic acid enhances the susceptibility of human colorectal cancer cells to 5-fluorouracil. Cancer Chemother. Pharmacol. 55, 12-20.

16. Calviello, G., F. Resci, S. Serini, E. Piccioni, A. Toesca, A. Boninsegna, G. Monego, F. O. Ranelletti, and P. Palozza. 2007. Docosahexaenoic acid induces proteasome-dependent degradation of beta-catenin, down-regulation of survivin and apoptosis in human colorectal cancer cells not expressing COX-2. Carcinogenesis 28, 1202-1209.

17. Calviello, G., S. Serini, and E. Piccioni. 2007. n-3 polyunsaturated fatty acids and the prevention of colorectal cancer: molecular mechanisms involved. Curr. Med. Chem. 14, 3059-3069.

18. Cannizzo, F., Jr. and S. A. Broitman. 1989. Postpromotional effects of dietary marine or safflower oils on large bowel or pulmonary implants of CT-26 in mice. Cancer Res. 49, 4289-4294.

19. Clevers, H. 2006. Wnt/beta-catenin signaling in development and disease. Cell 127, 469-480.

20. Collett, E. D., L. A. Davidson, Y. Y. Fan, J. R. Lupton, and R. S. Chapkin. 2001. n-6 and n-3 polyunsaturated fatty acids differentially modulate oncogenic Ras activation in colonocytes. Am. J. Physiol. Cell Physiol. 280, C1066-C1075.

21. Connolly, J. M., M. Coleman, and D. P. Rose. 1997. Effects of dietary fatty acids on DU145 human prostate cancer cell growth in athymic nude mice. Nutr. Cancer. 29, 114-119.

22. Connolly, J. M., E. M. Gilhooly, and D. P. Rose. 1999. Effects of reduced dietary linoleic acid intake, alone or combined with an algal source of docosahexaenoic acid, on MDA-MB-231 breast cancer cell growth and apoptosis in nude mice. Nutr. Cancer. 35, 44-49.

23. Danbara, N., T. Yuri, M. Tsujita-Kyutoku, M. Sato, H.
Senzaki, H. Takada, T. Hada, T. Miyazawa, K. Okazaki, and A. Tsubura. 2004. Conjugated docosahexaenoic acid is a potent inducer of cell cycle arrest and apoptosis and inhibits growth of colo 201 human colon cancer cells. Nutr. Cancer 50, 71-79.

24. Eberhardt, W., A. Huwiler, K. F. Beck, S. Walpen, and J. Pfeilschifter. 2000. Amplification of IL-1 beta-induced matrix metalloproteinase- 9 expression by superoxide in rat glomerular mesangial cells is mediated by increased activities of NF-kappa B and activating protein-1 and involves activation of the mitogen-activated protein kinase pathways. J. Immunol. 165, 5788-5797.

25. Eeckhout, Y. and G. Vaes. 1977. Further studies on the activation of procollagenase, the latent precursor of bone collagenase. Effects of lysosomal cathepsin B, plasmin and kallikrein, and spontaneous activation. Biochem. J. 166, 21-31.

26. Gago-Dominguez, M., J. M. Yuan, C. L. Sun, H. P. Lee, and M. C. Yu. 2003. Opposing effects of dietary n-3 and n-6 fatty acids on mammary carcinogenesis: The Singapore Chinese Health Study. Br. J. Cancer 89, 1686-1692.

27. Gatta, G., L. Ciccolallo, R. Capocaccia, M. P. Coleman, T. Hakulinen, H. Moller, and F. Berrino. 2003. Differences in colorectal cancer survival between European and US populations: the importance of sub-site and morphology. Eur. J. Cancer 39, 2214-2222.

28. Gordon, M. D. and R. Nusse. 2006. Wnt signaling: multiple pathways, multiple receptors, and multiple transcription factors. J. Biol. Chem. 281, 22429-22433.

29. Hardman, W. E. 2004. (n-3) fatty acids and cancer therapy. J. Nutr. 134, 3427S-3430S.

30. Hardman, W. E., C. J. Barnes, C. W. Knight, and I. L. Cameron. 1997. Effects of iron supplementation and ET-18-OCH3 on MDA-MB 231 breast carcinomas in nude mice consuming a fish oil diet. Br. J. Cancer 76, 347-354.

31. Hardman, W. E., M. P. Moyer, and I. L. Cameron. 1999. Fish oil supplementation enhanced CPT-11 (irinotecan) efficacy against MCF7 breast carcinoma xenografts and ameliorated intestinal side-effects. Br. J. Cancer 81, 440-448.

32. Hardman, W. E., M. P. Moyer, and I. L. Cameron. 2000. Dietary fish oil sensitizes A549 lung xenografts to doxorubicin chemotherapy. Cancer Lett. 151, 145-151.

33. Hoppler, S. and C. L. Kavanagh. 2007. Wnt signalling: variety at the core. J. Cell Sci. 120, 385-393.

34. Iigo, M., T. Nakagawa, C. Ishikawa, Y. Iwahori, M. Asamoto, K. Yazawa, E. Araki, and H. Tsuda. 1997. Inhibitory effects of docosahexaenoic acid on colon carcinoma 26 metastasis to the lung. Br. J. Cancer 75, 650-655.

35. Jemal, A., T. Murray, A. Samuels, A. Ghafoor, E. Ward, and M. J. Thun. 2003. Cancer statistics, 2003. CA. Cancer J. Clin. 53, 5-26.

36. Kim, J. S., Y. C. Lee, H. T. Nam, G. Li, E. J. Yun, K. S. Song, K. S. Seo, J. H. Park, J. W. Ahn, O. Zee, J. I. Park, W. H. Yoon, K. Lim, and B. D. Hwang. 2007. Apicularen A induces cell death through Fas ligand up-regulation and microtubule disruption by tubulin down-regulation in HM7 human colon cancer cells. Clin. Cancer Res. 13, 6509-6517. 
37. Kimura, Y. 2002. Carp oil or oleic acid, but not linoleic acid or linolenic acid, inhibits tumor growth and metastasis in Lewis lung carcinoma-bearing mice. J. Nutr. 132, 2069-2075.

38. Kinzler, K. W. and B. Vogelstein. 1996. Lessons from hereditary colorectal cancer. Cell 87, 159-170.

39. Kobayashi, N., R. J. Barnard, S. M. Henning, D. Elashoff, S. T. Reddy, P. Cohen, P. Leung, J. Hong-Gonzalez, S. J. Freedland, J. Said, D. Gui, N. P. Seeram, L. M. Popoviciu, D. Bagga, D. Heber, J. A. Glaspy, and W. J. Aronson. 2006. Effect of altering dietary omega-6/omega-3 fatty acid ratios on prostate cancer membrane composition, cyclooxygenase-2, and prostaglandin E2. Clin. Cancer Res. 12, 4662-4670.

40. Konstantinopoulos, P. A., G. P. Vandoros, M. V. Karamouzis, M. Gkermpesi, G. Sotiropoulou-Bonikou, and A. G. Papavassiliou. 2007. EGF-R is expressed and AP-1 and NF-kappaB are activated in stromal myofibroblasts surrounding colon adenocarcinomas paralleling expression of COX-2 and VEGF. Cell Oncol. 29, 477-482.

41. Kromhout, D. 1990. The importance of N-6 and N-3 fatty acids in carcinogenesis. Med. Oncol. Tumor. Pharmacother. 7, $173-176$

42. Lanier, A. P., T. R. Bender, W. J. Blot, J. F. Fraumeni, Jr., and W. B. Hurlburt. 1976. Cancer incidence in Alaska natives. Int. J. Cancer 18, 409-12.

43. Laurier, J. 2006. Alarming increase in cancer rates. WHO report $21,02$.

44. Lim, K., C. Han, L. Xu, K. Isse, A. J. Demetris, and T. Wu. 2008. Cyclooxygenase-2-derived prostaglandin E2 activates beta-catenin in human cholangiocarcinoma cells: evidence for inhibition of these signaling pathways by omega 3 polyunsaturated fatty acids. Cancer Res. 68, 553-560.

45. Liotta, L. A. 1984. Tumor invasion and metastases: role of the basement membrane. Warner-Lambert Parke-Davis Award lecture. Am. J. Pathol. 117, 339-348.

46. Liu, G., D. M. Bibus, A. M. Bode, W. Y. Ma, R. T. Holman, and Z. Dong. 2001. Omega 3 but not omega 6 fatty acids inhibit AP-1 activity and cell transformation in JB6 cells. Proc. Natl. Acad. Sci. USA 98, 7510-7515.

47. Llor, X., E. Pons, A. Roca, M. Alvarez, J. Mane, F. Fernandez-Banares, and M. A. Gassull. 2003. The effects of fish oil, olive oil, oleic acid and linoleic acid on colorectal neoplastic processes. Clin. Nutr. 22, 71-79.

48. Lyon. 2003. World Health Organization. The World Cancer Report.

49. Maillard, V., P. Bougnoux, P. Ferrari, M. L. Jourdan, M. Pinault, F. Lavillonniere, G. Body, O. Le Floch, and V. Chajes. 2002. N-3 and N-6 fatty acids in breast adipose tissue and relative risk of breast cancer in a case-control study in Tours, France. Int. J. Cancer 98, 78-83.

50. McCarty, M. F. 1996. Fish oil may impede tumour angiogenesis and invasiveness by down-regulating protein kinase $\mathrm{C}$ and modulating eicosanoid production. Med. Hypotheses 46, 107-115.

51. Miller, M., M. Motevalli, D. Westphal, and P. O. Kwiterovich, Jr. 1993. Incorporation of oleic acid and eicosa- pentaenoic acid into glycerolipids of cultured normal human fibroblasts. Lipids 28, 1-5.

52. Minami, Y., Y. Nishino, Y. Tsubono, I. Tsuji, and S. Hisamichi. 2006. Increase of colon and rectal cancer incidence rates in Japan: trends in incidence rates in Miyagi Prefecture, 1959-1997. J Epidemiol. 16, 240-248.

53. Minoura, T., T. Takata, M. Sakaguchi, H. Takada, M. Yamamura, K. Hioki, and M. Yamamoto. 1988. Effect of dietary eicosapentaenoic acid on azoxymethane-induced colon carcinogenesis in rats. Cancer Res. 48, 4790-4794.

54. Moon, R. T., A. D. Kohn, G. V. De Ferrari, and A. Kaykas. 2004. WNT and beta-catenin signalling: diseases and therapies. Nat. Rev. Genet. 5, 691-701.

55. Nagase, H. and J. F. Woessner, Jr. 1999. Matrix metalloproteinases. J. Biol. Chem. 274, 21491-21494.

56. Narayanan, B. A., N. K. Narayanan, D. Desai, B. Pittman, and B. S. Reddy. 2004. Effects of a combination of docosahexaenoic acid and 1,4-phenylene bis(methylene) selenocyanate on cyclooxygenase 2, inducible nitric oxide synthase and beta-catenin pathways in colon cancer cells. Carcinogenesis 25, 2443-2449.

57. Narayanan, B. A., N. K. Narayanan, B. Simi, and B. S. Reddy. 2003. Modulation of inducible nitric oxide synthase and related proinflammatory genes by the omega- 3 fatty acid docosahexaenoic acid in human colon cancer cells. Cancer Res. 63, 972-979.

58. Norat, T., A. Lukanova, P. Ferrari, and E. Riboli. 2002. Meat consumption and colorectal cancer risk: an estimate of attributable and preventable fractions. IARC. Sci. Publ. 156, 223-225.

59. Okada, Y., Y. Gonoji, K. Naka, K. Tomita, I. Nakanishi, K. Iwata, K. Yamashita, and T. Hayakawa. 1992. Matrix metalloproteinase 9 (92-kDa gelatinase/type IV collagenase) from HT 1080 human fibrosarcoma cells. Purification and activation of the precursor and enzymic properties. J. Biol. Chem. 267, 21712-21719.

60. Paulsen, J. E., I. K. Elvsaas, I. L. Steffensen, and J. Alexander. 1997. A fish oil derived concentrate enriched in eicosapentaenoic and docosahexaenoic acid as ethyl ester suppresses the formation and growth of intestinal polyps in the Min mouse. Carcinogenesis 18, 1905-1910.

61. Reddy, B. S. 2004. Omega-3 fatty acids in colorectal cancer prevention. Int. J. Cancer 112, 1-7.

62. Reddy, B. S. and H. Maruyama. 1986. Effect of dietary fish oil on azoxymethane-induced colon carcinogenesis in male F344 rats. Cancer Res. 46, 3367-3370.

63. Rose, D. P. and J. M. Connolly. 1990. Effects of fatty acids and inhibitors of eicosanoid synthesis on the growth of a human breast cancer cell line in culture. Cancer Res. 50, 7139-7144.

64. Rose, D. P. and J. M. Connolly. 2000. Regulation of tumor angiogenesis by dietary fatty acids and eicosanoids. Nutr. Cancer 37, 119-127.

65. Roynette, C. E., P. C. Calder, Y. M. Dupertuis, and C. Pichard. 2004. n-3 polyunsaturated fatty acids and colon cancer prevention. Clin. Nutr. 23, 139-151. 
66. Rubinfeld, B., B. Souza, I. Albert, O. Muller, S. H. Chamberlain, F. R. Masiarz, S. Munemitsu, and P. Polakis. 1993. Association of the APC gene product with beta-catenin. Science 262, 1731-1734.

67. Sandhu, M. S., I. R. White, and K. McPherson. 2001. Systematic review of the prospective cohort studies on meat consumption and colorectal cancer risk: a meta-analytical approach. Cancer Epidemiol Biomarkers Prev. 10, 439-446.

68. Schonberg, S. A., A. G. Lundemo, T. Fladvad, K. Holmgren, H. Bremseth, A. Nilsen, O. Gederaas, K. E. Tvedt, K. W. Egeberg, and H. E. Krokan. 2006. Closely related colon cancer cell lines display different sensitivity to polyunsaturated fatty acids, accumulate different lipid classes and downregulate sterol regulatory element-binding protein 1. Febs. J. 273, 2749-2765.

69. Schwartz, S. A., A. Hernandez, and B. Mark Evers. 1999. The role of NF-kappaB/IkappaB proteins in cancer: implications for novel treatment strategies. Surg. Oncol. 8, 143-153.

70. Simonsen, N., P. van't Veer, J. J. Strain, J. M. Martin-Moreno, J. K. Huttunen, J. F. Navajas, B. C. Martin, M. Thamm, A. F. Kardinaal, F. J. Kok, and L. Kohlmeier. 1998. Adipose tissue omega-3 and omega- 6 fatty acid content and breast cancer in the EURAMIC study. European Community Multicenter Study on Antioxidants, Myocardial Infarction, and Breast Cancer. Am. J. Epidemiol. 147, 342-352.

71. Simopoulos, A. P. 2002. The importance of the ratio of omega-6/omega-3 essential fatty acids. Biomed. Pharmacother. 56, 365-379.

72. Song, K. S. and K. Lim. 2008. Tumorigenicity and angiogenesis of pancreatic cancer are inhibitied in Fat1 transgenic mice. Int. Conferance Anticancer Res. 406, 3380.

73. Spector, A. A. 1999. Essentiality of fatty acids. Lipids. 34 Suppl, S1-S3.

74. Stewart, B. W. and P. Kleihues. 2003. Increase in global cancer rates. The World Cancer report. 2, 4.

75. Su, L. K., B. Vogelstein, and K. W. Kinzler. 1993. Association of the APC tumor suppressor protein with catenins. Science 262, 1734-1737.

76. Suzuki, K., J. J. Enghild, T. Morodomi, G. Salvesen, and H. Nagase. 1990. Mechanisms of activation of tissue procollagenase by matrix metalloproteinase 3 (stromelysin). Biochemistry 29, 10261-10270.

77. Szymczak, M., M. Murray, and N. Petrovic. 2008. Modulation of angiogenesis by omega-3 polyunsaturated fatty acids is mediated by cyclooxygenases. Blood 111, 3514-3521.
78. Takahashi, M., M. Fukutake, T. Isoi, K. Fukuda, H. Sato, K. Yazawa, T. Sugimura, and K. Wakabayashi. 1997. Suppression of azoxymethane-induced rat colon carcinoma development by a fish oil component, docosahexaenoic acid (DHA). Carcinogenesis 18, 1337-1342.

79. Takahashi, M., T. Minamoto, N. Yamashita, T. Kato, K. Yazawa, and H. Esumi. 1994. Effect of docosahexaenoic acid on azoxymethane-induced colon carcinogenesis in rats. Cancer Lett. 83, 177-184.

80. Tong, Q., L. Zheng, L. Lin, B. Li, D. Wang, C. Huang, G. M. Matuschak, and D. Li. 2006. Participation of the PI-3K/Akt-NF-kappa B signaling pathways in hypoxia-induced mitogenic factor-stimulated Flk-1 expression in endothelial cells. Respir. Res. 7, 101.

81. Trifan, O. C. and T. Hla. 2003. Cyclooxygenase-2 modulates cellular growth and promotes tumorigenesis. J. Cell Mol. Med. 7, 207-222.

82. Weldon, S. M., A. C. Mullen, C. E. Loscher, L. A. Hurley, and H. M. Roche. 2007. Docosahexaenoic acid induces an anti-inflammatory profile in lipopolysaccharide-stimulated human THP-1 macrophages more effectively than eicosapentaenoic acid. J. Nutr. Biochem. 18, 250-258.

83. Willett, W. C., M. J. Stampfer, G. A. Colditz, B. A. Rosner, and F. E. Speizer. 1990. Relation of meat, fat, and fiber intake to the risk of colon cancer in a prospective study among women. N. Engl. J. Med. 323, 1664-1672.

84. Xia, S. H., J. Wang, and J. X. Kang. 2005. Decreased n-6/n-3 fatty acid ratio reduces the invasive potential of human lung cancer cells by downregulation of cell adhesion/invasion-related genes. Carcinogenesis 26, 779-784.

85. Yoon, W. H., Y. J. Jung, T. D. Kim, G. Li, B. J. Park, J. Y. Kim, Y. C. Lee, J. M. Kim, J. I. Park, H. D. Park, Z. S. No, K. Lim, B. D. Hwang, and Y. S. Kim. 2004. Gabexate mesilate inhibits colon cancer growth, invasion, and metastasis by reducing matrix metalloproteinases and angiogenesis. Clin. Cancer Res. 10, 4517-4526.

86. Yun, E. J., K. S. Song, J. S. Kim, J. Y. Heo, Y. J. Jung, C. Han, T. Wu, J. K. Kang, J. I. Park, G. R. Kweon, W. H. Yoon, B. D. Hwang, and K. Lim. 2008. DHA suppresses cell invasion through inhibitions of matrix metalloproteinases, vascular EGF and Cox-2 in breast cancer cells. AACR.

87. Zhao, Y., S. Joshi-Barve, S. Barve, and L. H. Chen. 2004. Eicosapentaenoic acid prevents LPS-induced TNF-alpha expression by preventing NF-kappaB activation. J. Am. Coll. Nutr. 23, 71-78. 
초록 : 인체 대장암 세포주 SW480에서 docosahexaenoic acid에 의한 침윤억제 기전

신소연 $^{1,3+} \cdot$ 김용조 ${ }^{1+} \cdot$ 송경섭 ${ }^{1,3^{\dagger}} \cdot$ Kaipeng $\mathrm{Jing}^{1,3} \cdot$ 김나영 ${ }^{1,3} \cdot$ 정소연 ${ }^{1,3} \cdot$ 박지훈 ${ }^{1} \cdot$ 서강식 $^{1} \cdot$ 허준영 ${ }^{1} \cdot$

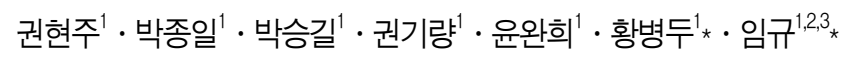

('충남대학교 의학전문대학원 생화학교실, ${ }^{2}$ 충남대학교 암연구소, ${ }^{3}$ 감염신호네트워크연구센타)

대장암은 미국 등 서양 국가뿐만 아니라 국내에서도 2번째로 많이 발병이 되는 암으로 알려져 있다. 역학조사 에 의하면 $\omega 3-P U F A s$ 를 많이 섭취한 인종에서 대장암 발생빈도가 감소하고 최근 $\omega 3-P U F A s$ 는 수종의 암에 대해 항암작용을 나타낸다고 한다. 이에 본 연구에서는 대장암에서 DHA 등 $\omega 3$-PUFA의 항침윤 기전을 규명하여 다음 과 같은 결과를 얻었다. $\mathrm{DHA}$ 및 $\mathrm{EPA}$ 는 대장암 세포주 SW480의 증식을 농도 의존적으로 억제하였으나 $\mathrm{AA}$ 는 거의 영향이 없었으며 TUNEL assay로 apoptotic cell death가 확인 되었다. DHA는 $\beta$-catenin 단백 및 TCF/LEF luciferase 활성을 농도 의존적으로 억제 하였다. SW480 세포의 침윤능은 DHA의 농도에 의존적으로 억제되었다. DHA처리 후 MMP-9 및 MMP-2 mRNA양이 감소되었을 뿐만 아니라 그 promoter의 reporter 활성도 억제되었 다. NF-kB 및 p-IkB 단백질양도 DHA의 처리농도에 의존적으로 감소하였으며 NF-kB promoter의 활성도 억제되 었다. 이상의 결과로 $\omega 3$-PUFA는 대장암에서 NF-kB 신호전달 차단에 의한 MMP-2 및 MMP-9 발현을 억제하여 침윤을 억제하여 항암작용을 나타낼 수 있음을 시사하며, 따라서 $\omega 3$-PUFA는 대장암의 예방 및 치료에 유용하게 사용될 수 있으리라 생각된다. 